\title{
Effect of Botanicals in Combination with Wheat Straw on the Growth of Oyster Mushroom (Pleurotus florida)
}

\author{
Mark Prasanth*, Sobita Simon and Ch. Ribca Thessy \\ Department of Plant Pathology, Sam Higginbottom University of Agriculture, Technology and \\ Sciences, Prayagraj- 211 007, India \\ *Corresponding author
}

Keywords

basil, guava, neem, lantana, oyster mushroom, turmeric

Article Info

Accepted:

12 March 2021

Available Online:

10 April 2021
The research experiment was carried out using the Botanicals with wheat straw to evaluate the growth and yield parameters of oyster mushroom (Pleurotus florida). The botanicals were evaluated in combination with wheat straw (wheat straw + Neem, wheat straw + Lantana, wheat straw + Turmeric, wheat straw + Guava, wheat straw + basil and wheat straw alone) to find out best botanical supplemented that support the growth of oyster mushroom. Each treatments were replicated five times under completely randomized block design. The minimum time taken for complete spawn run (14 days), primordial initiation (16 days), fruiting bodies formation (18 days), maximum yield $(3,792 \mathrm{~g} / \mathrm{kg}$ ) and cost benefit ratio (7.28:1) were recorded (wheat straw + Basil) followed by wheat straw + Neem $(3,509)$, wheat straw + Turmeric $(3,438)$, wheat straw alone $(2,736)$, wheat straw + Lantana $(2,649)$ and wheat straw + Guava $(1,351)$.

\section{Introduction}

Mushrooms are fleshy, spore-bearing reproductive structures of fungi grown on organic substrates and for a long time, have played an important role as human food due to its nutritional and medicinal properties (Ng'etich et al., 2013) and area rich source of proteins, minerals and vitamins (Caglarirmak, 2007). Mushrooms with their flavour, texture, nutritional value and high productivity per unit area have been identified as an excellent food source to alleviate malnutrition in developing countries (Eswaran and Ramabadran, 2000).

Oyster mushroom popularly known as "Dhingri" in India is fan or spatula shaped with different shades of white, pink, yellow, grey, blue depending upon the species. The common name "oyster mushroom" comes from the white shell-like appearance of the fruiting body (Stanley and Odu, 2012). Oyster mushroom is an edible mushroom having excellent flavour and taste. It has high protein 
content and has many other constituents such as vitamin B1,B2 and low calorie levels.(Stanley et al., 2011) reported a high nutritional values of Pleurotus florida with protein $(25-50 \%)$, fat $(2-5 \%)$, sugars (17 $47 \%)$, mycocellulose $(7-38 \%)$ and minerals (potassium, phosphorus, calcium and sodium) of about $8-12 \%$. They also possess a number of medicinal properties, such as antitumour, immunomodulatory, anti-genotoxic, antioxidant, anti-inflammatory, hypocholesterolaemic, anti-hypertensive, antiplatelet-aggregating, anti-hyperglycaemic, antimicrobial and antiviral activities (Gregori et al., 2007). Mushrooms may be grown on wide range of plant waste as substrate e.g. sawdust, paddy straw, sugarcane baggage, corn stalk, corn cobs, waste cotton, leaves and pseudo stem of banana, water hyacinth, duck weed and rice straw etc thus not requiring costly processing method and enrichment. Wheat straw is the principal substrate for oyster mushroom growing, although adequate production can be achieved through use of wheat straw with the addition of supplements that substantially increase the yield per unit weight (Baysal et al., 2003).

In terms of world mushroom production, Pleurotus spp. rates second, after Agaricus bisporus, accounting for $25 \%$ of total world production of cultivated mushrooms. There has been significant increase in production of mushrooms in the last few years, especially of the oyster and paddy straw mushrooms in India. Presently oyster mushroom contribute to about $19 \%$ in terms of total mushroom production in the world. The global mushroom industry has expanded very rapidly in the last two decades by the addition of newer types of mushrooms for commercial cultivation.

Cultivation of mushrooms on lignocellulosic wastes represents one of the most economically and cost-effective organic recycling processes. Oyster mushroom is characterized by its high protein content and gourmet food quality, thus surpassing many other foods. Unlike other mushroom species, oyster mushrooms are the easiest, fastest and cheapest to grow, require less preparation time and production technology. Also, the first flush is usually large, without the need for compost, manure and limestone or casing. With more than $100 \%$ biological efficiency, coupled with its distinctive flavour, aroma and excellent drying and preservation qualities, it is assured a unique status as a delicacy. Wheat straw is generally used as a base substrate for cultivation of wheat straw. However the low digestibility, low protein content and high lignin hinder the growth of oyster mushroom (Mandeel et al., 2005).

\section{Materials and Methods}

The experiment was carried out in the Mushroom Crop Room and Research Laboratory, Department of Plant Pathology, SHUATS, Prayagraj, 211007 (U.P.).India during the period of October 2020 to December 2020. The base substrate locally available wheat straw (Triticum aestivum) supplemented with botanicals collected from local area. Spawn of Pleurotus florida was procured from Department of Plant Pathology, SHUATS, Prayagraj U.P., India.

\section{Substrate preparation}

According the method of (Sohi, 1987) Wheat straw was used as the base substrate for all the treatments. The straw was sun dried and cut into small pieces $(2-3 \mathrm{~cm})$. Fifty liters of tap water was filled in a plastic drum of 100 liter capacity. A solution was prepared with formaldehyde $(120 \mathrm{ml})$, calcium carbonate $(150 \mathrm{~g})$ and carbendazim $(7.5 \mathrm{~g})$ in water and stirred properly with a stick and the dry wheat straw substrate $(20 \mathrm{~kg}$ ) was slowly steeped completely in the solution. The mouth of the plastic drum was sealed with the lid. After 18 
hours of sterilization, the straw was taken out and the excess water was drained and spread out as thin layer on sterilized plastic sheet spread or on cemented floor in a shaded area.

The straw was left for 2-3 hours to reduced into (60-65\%) moisture which is checked by taking a handful of straw and squeezing tightly if water does not drip from the substrate and it is moist, the substrate is ready for spawning.

\section{Preparation of botanicals}

The selected plants (neem, lantana camera, turmeric, guava and basil) were procured from different locations in and around the university campus. It was then weighed, washed and dried after which it was powdered and packed in polypropylene bags and sealed. The bags with leaf powder were autoclaved at $121^{\circ} \mathrm{C}$ at $15 \mathrm{psi}$ for $1 / 2$ hours. The prepared botanical leaf powder was mixed into the wheat straw at the rate of $50 \mathrm{~g}$ per $2 \mathrm{~kg}$ wet substrate.

\section{Spawning and bagging}

Spawning was done at the rate of $50 \mathrm{~g}$ per $2 \mathrm{~kg}$ of wet substrates. Before filing into the bags the substrates were mixed thoroughly with layer method was packed into the polythene bags and mouth of the spawned bag was tied with the help of nylon string. For perforation, 8-10 holes were made in each bag with the help of nail to allow free passage of air within the bags. Five replications for each treatment were maintained. These bags after inoculation were then incubated for spawn running in a dark mushroom crop room at ambient temperature i.e temperature at $\left(20-25^{\circ} \mathrm{C}\right)$ and humidity at (70-85). The spawned bags were kept at distance of $(20-25 \mathrm{~cm})$ in the mushroom crop room until the mycelium fully colonized the substrate. When the bags were completely colonized by the mushroom mycelium, the polythene bags were cut and removed. The substrates were sprayed with water 3-4 times per day. After 3-5 days of removal of polythene bags small pin heads appeared on all sides of bags. Further to regulate the oxygen and carbon dioxide levels, the crop room was opened to get light for 1- 2 hours every day. The present study, completely randomized design (CRD) was applied for the analysis of the recorded data.

The conclusions were drawn on the basis of analysis of variance. The calculated $\mathrm{F}$ was compared with the tabulated 5\% level of probability at the appropriate degree of freedom (Fisher and Yates, 1986).

\section{Results and Discussion}

The research experiment was carried out using the Botanicals with wheat straw to evaluate the growth and yield parameters of oyster mushroom (Pleurotus florida). The botanicals were evaluated in combination with wheat straw (Wheat straw + Neem, Wheat straw + Lantana, Wheat straw + Turmeric, Wheat straw + Guava, Wheat straw + basil and wheat straw alone). The findings reveal that supplemented bags have better results in terms of growth stages and yield than the one without supplementation. Among the five supplements Wheat straw + basil show superiority than other supplements. The results obtained from this study, the minimum time was recorded in $\mathrm{T}_{5}$ Basil + wheat straw Complete spawn run (14 days), Primodial initiation (16 days), Maturation of fruting body (18 days).

The maximum yield was recorded in Basil + wheat straw $(3,792 \mathrm{~g} / \mathrm{kg})$ followed by Neem + wheat straw $(17,20,23,3,509 \mathrm{~g} / \mathrm{kg})$,Turmeric + wheat straw $(16,19,23,3,438 \mathrm{~g} / \mathrm{kg})$, Lantana + wheat straw (22, 26, 29, 2,649 $\mathrm{g} / \mathrm{kg})$, Guava + wheat straw $(34,38,42,1,351$ $\mathrm{g} / \mathrm{kg}$ ), respectively as compared to wheat straw alone $(21,24,28,2,736 \mathrm{~g} / \mathrm{kg})$. 
Table.1 Effect on combinations of wheat straw and supplements doses on growth and yield of Pleurotus florida

\begin{tabular}{|c|c|c|c|c|}
\hline $\begin{array}{c}\text { Substrate } \\
\text { combinations }\end{array}$ & Spawn run & $\begin{array}{c}\text { Primodial } \\
\text { initiation }\end{array}$ & $\begin{array}{c}\text { Maturation } \\
\text { of fruiting } \\
\text { body }\end{array}$ & $\begin{array}{c}\text { Yield } \\
\text { (g/kg) }\end{array}$ \\
\hline Wheat straw & 21.4 & 24.4 & 28.4 & 2,736 \\
\hline Neem + wheat straw & 17.4 & 20.4 & 23.8 & 3,509 \\
\hline $\begin{array}{c}\text { Lantana + wheat } \\
\text { straw }\end{array}$ & 22.8 & 26.2 & 29.6 & 2,649 \\
\hline $\begin{array}{c}\text { Turmeric + wheat } \\
\text { straw }\end{array}$ & 16.8 & 19.4 & 23.00 & 3,438 \\
\hline Guava + wheat straw & 34.2 & 38.2 & 42.2 & 1,351 \\
\hline Basil + wheat straw & 14.4 & 16.4 & 18.6 & 3,792 \\
\hline CD (at 5\%) & $\mathbf{1 . 0 0 3}$ & $\mathbf{0 . 7 7 7}$ & $\mathbf{0 . 9 7 4}$ & $\mathbf{1 4 . 6 0 5}$ \\
\hline
\end{tabular}

Fig.1 Effect on combinations of wheat straw and supplements doses on growth of Pleurotus florida.

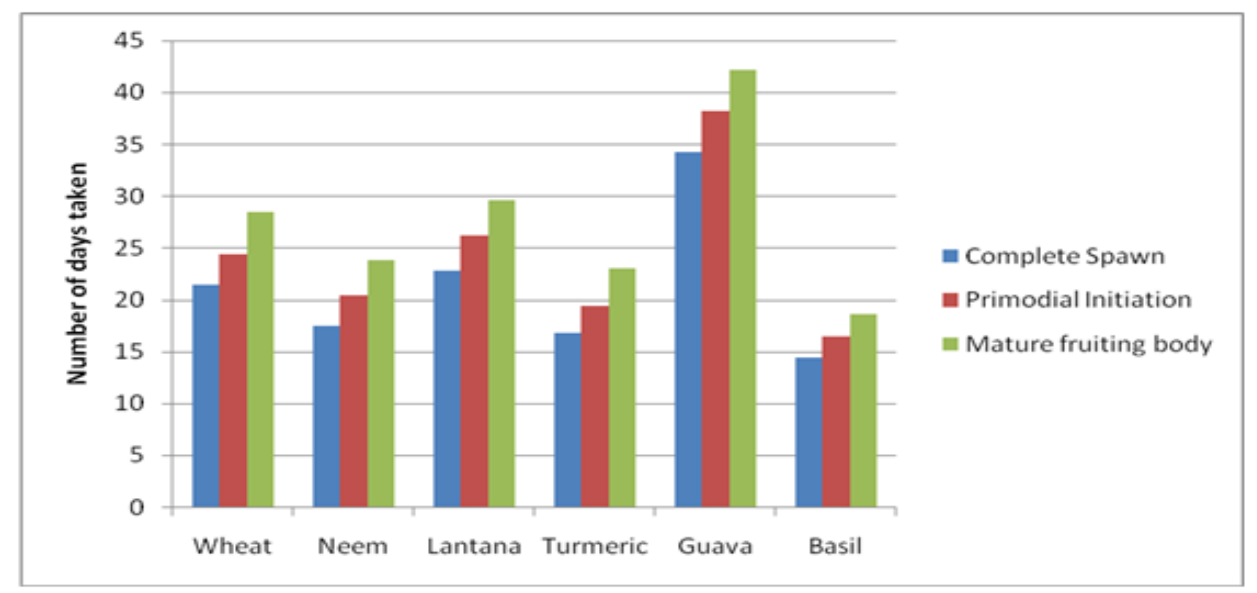

Fig.2 Effect on combinations of wheat straw and supplements doses on yield of Pleurotus florida.

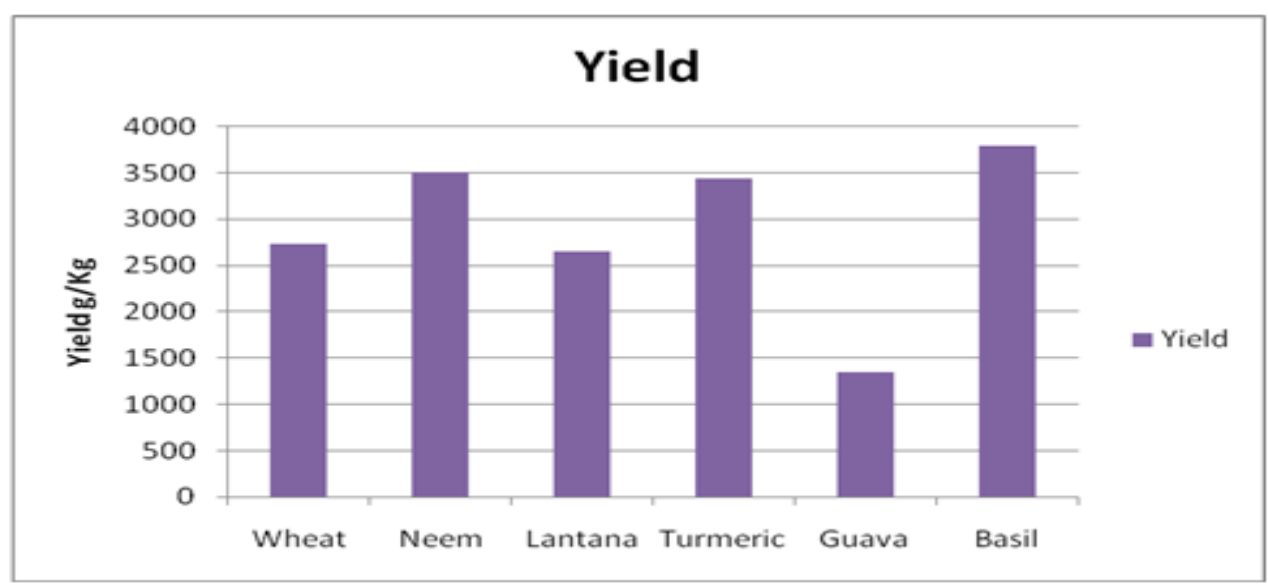


Therefore, it can be concluded that the use of Basil leaves +wheat straw for cultivation of Pleurotus florida recorded minimum days taken for spawn run, pin head initiation, fruiting bodies formation, highest average pileus width $(\mathrm{cm})$, stipe length $(\mathrm{cm})$, highest yield (g) was recorded, that the addition of basil leaves to the wheat substrate show significant results in improving the quality and quantity parameters of the mushroom. This may be due to the effect of the antimicrobial substances found in basil which contain a mixture of Phenolic compounds, Flavonoids, Rosmarinic acid, Eugenols, Ocimene, Tannins and Perilly alcohol which inhibit growth of other competitor moulds and enables the mushroom mycelium to fully absorb the available nutrients i.e., carbon, nitrogen, phosphorus and potassium also basil has high cellulose and low lignin content which which helps in decomposition of the substrates and the result is faster growth of the mushroom.

\section{References}

Baysal, E., Peker, H., Yalinkiliç, K. M. and Temiz, A. (2003).Cultivation of oyster mushroom on waste paper with some added supplementary materials. Bioresource Technology. 89: 95-97.

Caglarirmak, N. (2007). The nutrients of exotic mushrooms (Lentinulaedodes and Pleurotusspp) and an estimated approach to the volatile compounds. Food Chemistry.105: 1188-1194.

Eswaran, A. and Ramabadran, R. (2000). Studies on some physiological, cultural and post harvest aspects of oyster mushroom, Pleurotuso streatus. Tropical Agricicultural Resources.12:360-374.

Fisher, R. A. and Yates, F. (1986). Statistical Tables for Biological, Agricultural and Medical Research. Biometrical Journal.6: 46-50.

Gregori, A., Svagelj, M. and Pohleven, J.(2007). Cultivation techniques and medicinal properties of Pleurotus florida. Food Technology and Biotechnology.45:238-249.

Mandeel(2005). Cultivation of oyster mushrooms (Pleurotus spp.) on various lignocellulosic wastes. World Journal of Microbiology \& Biotechnology.21:601-607.

Ng'etich, O. K., Nyamangyoku, O. I., Rono, J. J., Niyokuri A. N. and Izamuhaye, J. C. (2013). Relative performance of oyster mushroom (Pleurotus florida) on agro-industrial and agricultural substrate. International journal of Agronomy and Plant Production.4: 109-116.

Stanley, H. O. and Odu, N. N. (2012). Cultivation of oyster mushroom (Pleurotus Tuber-Regium) on selected organic waste. International Journal of Advance Biological Research.2: 446448.

Sohi, H.S. (1987). Diseases and competitor moulds associated with mushroom culture and their control. Extension Bulletin.2: 10-12.

\section{How to cite this article:}

Mark Prasanth, Sobita Simon and Ribca Thessy, Ch. 2021. Effect of Botanicals in Combination with Wheat Straw on the Growth of Oyster Mushroom (Pleurotus florida). Int.J.Curr.Microbiol.App.Sci. 10(04): 297-301. doi: https://doi.org/10.20546/ijcmas.2021.1004.030 